\title{
Palavra poética, cor e história
}

\author{
Literatura e afrodescendência no \\ Brasil: antologia crítica. \\ DUARTE, Eduardo de Assis (Org.). \\ Coorganização com Maria Nazareth \\ Soares Fonseca do volume 4.
}

Belo Horizonte: UFMG, 2011 1. 2.028 p. 4 v.

Acaba de ser lançada, pela editora da UFMG, Literatura e afrodescendência no Brasil: antologia crítica, trabalho de fôlego que reúne em quatro volumes resultado de pesquisa liderada ao longo de mais de 10 anos pelo professor Eduardo de Assis Duarte dessa universidade. Fruto da colaboração de 61 pesquisadores de 21 universidades brasileiras $e$ 6 estrangeiras, tendo contado com o apoio de órgãos de fomento, diferentes instituições e inúmeros cidadãos e estudantes da UFMG, a obra necessariamente conduz a novas formas de pensar a Literatura Brasileira.

Lançando foco sobre 100 escritores afrodescendentes, vindos de tempos e espaços diversos, através de ensaios e referências biográficas e bibliográficas sobre cada um deles, dos tempos coloniais até os dias de hoje, a coletânea procura organizar a ainda dispersa reflexão acadêmica atual sobre o tema, num percurso histórico que vai de clássicos (Machado de Assis, Lima Barreto, Cruz e Sousa) a contemporâneos (Nei Lopes, Paulo Lins, Ana Maria Gonçalves), passando por nomes importantes 'esquecidos' (Maria Firmina dos Reis, José do Nascimento Moraes). A Antologia deixa claro que seu real objetivo é "mostrar que existe uma produção literária importante que caminha na contracorrente das normas ainda vigentes no circuito literário". Buscando mapear e conceituar, a Antologia

inclui escritos daqueles que mesmo não assumindo explicitamente um projeto literário afro-brasileiro (termo e conceituação contemporâneos), apresentam traços discursivos que os situam, em muitos momentos, numa órbita de valores socioculturais distintos dos abraçados pelas elites brancas. E que, de uma forma ou de outra, expressam tais valores, transformandoos em linguagem literária.
Nesse sentido, a obra se insere em categoria relevante dos Estudos Literários na contemporaneidade - a do resgate. Resgate de obras que, nas palavras da autora afro-americana Alice Walker, "por instintos contrários" ou por questões múltiplas de relações de poder e hegemonia, acabaram, como tantas outras, 'perdidas' ou 'esquecidas', apesar de produção literária consistente e valorosa. Rotas que necessariamente avançam na contemporaneidade ao se discutirem identidade e literatura. Nessa ótica, o trabalho de pesquisa liderado pelo professor Eduardo de Assis Duarte trilha caminhos próprios, porém semelhantes àqueles que foram decisivos nos Estados Unidos para o reconhecimento e a visibilidade da produção literária dos afrodescendentes, tal como o trabalho do renomado crítico afro-americano Henry Louis Gates Junior e seus estudos de arqueologia literária. Ligado a estudos pós-coloniais de literatura, ao cruzar gênero e etnia, apresentou descobertas absolutamente impensáveis até anos atrás entre os autores literários e que passaram, então, a embasar os currículos e redimensionar os estudos da literatura estadunidense.

Assim, em época de revisões, quando as ações afirmativas estão em torno dos 10 anos nas universidades no Brasil, a Antologia crítica ao lançar um novo olhar sobre a Literatura Brasileira, torna-se obra de referência e de encontro identitário para o amplo grupo de alunos afrodescendentes que ingressou na universidade pelo sistema de cotas e que tem sido submetido a currículos fundamentalmente eurocêntricos. É obra que servirá como fonte de referência para aqueles que devem aplicar a Lei n. 10.639/2003, que estabelece que "nos estabelecimentos de ensino fundamental e médio, oficiais e particulares, torna-se obrigatório o ensino sobre História e Cultura Afro-Brasileiras". '

Com metodologia rigorosa, liderança firme, metas claras e definidas, a obra constitui um marco, um ponto capital, e destaca-se no cenário da pesquisa propositiva em Letras em nosso país. Apresenta produto de trabalho sério e orgânico, organização, consistência e conteúdo crítico. Ao se impor o desafio de realizar pesquisa em todas as regióes do país (fato incomum na área, em geral voltada para aspectos pontuais) com vistas ao mapeamento (absolutamente inédito) e ao estudo da literatura produzida pelos afrodescendentes desde 0 
período colonial, traz contribuição de peso para os estudos dessa literatura em nosso país, colocando-nos, inclusive, em posição de destaque na Afro-América Latina.

Em brevíssimas linhas, um pouco da riqueza de cada um dos volumes. O Volume I Precursores - parte do século XVIII e se dedica a 31 autores e autoras nascidos até 1930. Passando por clássicos como Machado de Assis, Lima Barreto e Cruz e Sousa, chama a atenção também para escritores 'esquecidos' ou 'pouco lembrados' como o poeta do século XVII Domingos Caldas Barbosa e os pioneiros de meados do século XIX Luiz Gama e Maria Firmina dos Reis - autora de Úrsula (1859), o primeiro romance abolicionista do Brasil, cuja republicação em 2004, após mais de um século fora de circulação, vem contribuindo para a reescrita de nossa história literária. Chega ao século XX com Solano Trindade, Carolina Maria de Jesus $e$ Abdias Nascimento, entre outros. O volume abre com denso ensaio introdutório - "Entre Orfeu e Exu, a afrodescendência toma a palavra" - de autoria de seu organizador, Eduardo de Assis Duarte. Nesse ensaio são traçados de forma assertiva os pressupostos da Antologia crítica.

O Volume II - Consolidação - nos apresenta mais 30 autores e autoras nascidos nas décadas de 1930 e 1940, entre eles, os eminentes intelectuais afro-brasileiros Joel Rufino dos Santos e Muniz Sodré, o poeta e romancista Domício Proença Filho, membro da Academia Brasileira de Letras, e o compositor, escritor e pesquisador da cultura afro-brasileira Nei Lopes. Entre as mulheres, a poeta, contista, romancista e ensaísta Conceição Evaristo. O título do volume marca época quando se consolida a existência de uma vertente afro na Literatura Brasileira.

O Volume III - Contemporaneidade - reúne 39 autores e autoras nascidos na metade do século XX. Entre eles, o poeta e ficcionista Cuti; Marcio Barbosa e Esmeralda Ribeiro, mantenedores da decisiva série Cadernos Negros, publicação ativa desde 1978; Paulo Lins, autor de Cidade de Deus; Ana Maria Gonçalves, autora do romance histórico Um defeito de cor, vencedor do prestigiado prêmio Casa de las
Américas; e, ainda, Miriam Alves, Lia Vieira e, na nova geração, Cristiane Sobral, Cidinha da Silva e Allan da Rosa, entre outros, com temática predominantemente urbana e voltada para as populações marginalizadas nos grandes centros brasileiros.

O Volume IV - História, teoria, polêmica coorganizado com Maria Nazareth Soares Fonseca, encerra a presente série e abre novas perspectivas de avanços e formulações. Estruturado a partir de diferentes visões e impressões da sociedade brasileira e da literatura produzida por escritores afrodescendentes, reúne depoimentos de escritores e intelectuais negros, reflexões sobre a produção literária e sobre o próprio conceito de literatura afro-brasileira, refletindo sobre a multiplicidade e a diversidade de características da contemporaneidade. Os textos críticos problematizam a questão e são assinados, entre outros, por Octávio lanni e Silviano Santiago.

A obra terá lançamento nacional em pelo menos seis capitais do Brasil e um lançamento oficial no Rio de Janeiro, no Teatro Machado de Assis da Biblioteca Nacional, com a presença de autores incluídos na Antologia e uma homenagem a Abdias Nascimento. É o início da visibilidade do que até então não era visível ou conhecido, almejada ao longo de todo o texto por seu organizador.

\section{Notas}

' BRASIL, 2003.

\section{Referências}

BRASIL. Lei n. 10.639, de 9 de janeiro de 2003. Altera a Lei n. 9.394, de 20 de dezembro de 1996, que estabelece as diretrizes e bases da educação nacional, para incluir no currículo oficial da Rede de Ensino a obrigatoriedade da temática "História e Cultura Afro-Brasileira", e dá outras providências. Disponível em: <http:// www.planalto.gov.br/ccivil_03/leis/2003/ L10.639.htm>. Acesso em: $10^{-}$jun. 2011.

Maria Aparecida Andrade Salgueiro Universidade do Estado do Rio de Janeiro 